\title{
Pre and Post Cholecystectomy Ultrasound Screening of Hepatobiliary Tumours
}

\author{
Mukesh Pant ${ }^{1}$, Gupta $\mathbf{P}^{2}$ and *Virendra Singh ${ }^{3}$ \\ ${ }^{1}$ Senior Resident, Department of Radiodiagnosis, MLN Medical College, India \\ ${ }^{2}$ Associate Professor, General Medicine, MLN Medical College, India \\ ${ }^{3}$ Professor Radiotherpy, MLN Medical College, India
}

Submission: April 14, 2017; Published: April 24, 2017

"Correspondence Address: Virendra Singh, Professor Radiotherpy, MLN Medical College, India

\begin{abstract}
Ultrasound has evolved as a diagnostic procedure of choice for evaluation of hepatobiliary tumours. Cost effective approach uses ultrasound followed by endoscopic retrograde cholangio pancreatography where the presence of a "shelf" instead of s smooth taper to the stricture, can suggest a malignant etiology. Brushing and biopsy/five needle aspiration cytalogy will yield a definitive tissue diagnosis. Ultrasound is preferred to MRI as it is a love cost modality while CT Scan exposes patients to ionizing radiation.
\end{abstract}

Keywords: Cholecystectomy; Gall bladder; Ultrasound; Hepatobiliary; Tumors

\section{Introduction}

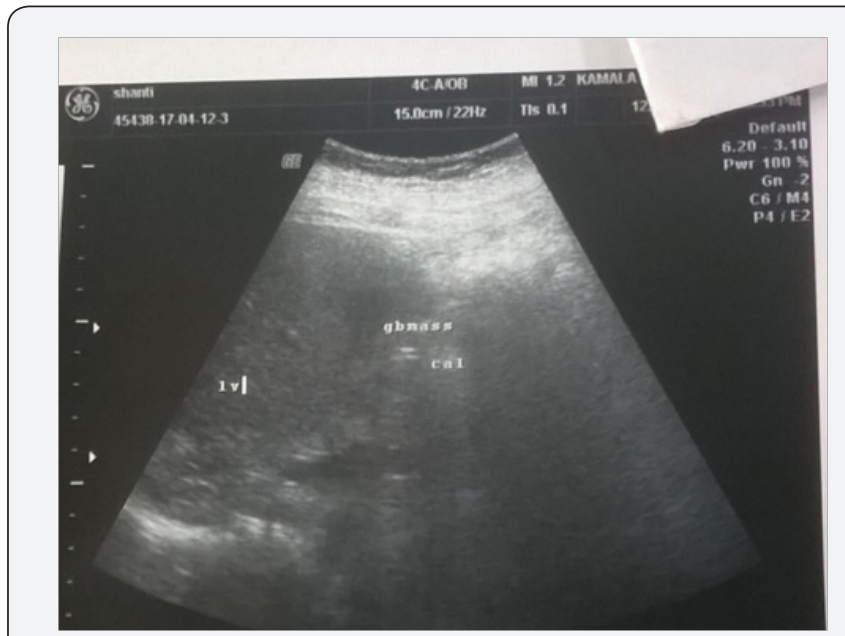

Figure 1: Cholelithiasis with Gall Bladder mass.

IUltrasound abdomen is a cost effective, non invasive radiation free technique for early detection of hepatobiliary tumors. Thickening of bile duct wall with proximal biliary dilatation are consistent with a "possible" tumors in biliary duct and thickening of Gall bladder wall for gall bladder tumor are equally visualized by MRI or ultrasound studies. Recent meta analysis [1-3] revealed that cholelithiasis and cholecystolithiasis may be involved the development of hepatobiliary cancer, especially for intrahepatic cholengiocarcioma. This review is undertaken to investigate the role pre and post cholecystectomy ultrasound screening of hepatobiliary tumors (Figure 1).

\section{Methods}

\section{Search Strategy}

Many reliable websites were searched especially Pubmed and National Institute of health to do this research. Subject heading terms were also added in all searches. Search terms include ultrasound, hepatobiliary tumours, cholecystectomy, screening, cholelithiasis Further we screened the reference, lists of the review articles and identified studies. All the searches were conducted independently by both the authors in March, 2015 and differences were resolved by discussion.

\section{Discussion}

\section{Summary of findings}

Magnetic resonance imaging with magnetic resonance cholangiopancreaticography, ultrasound or computerized tomography can be used for pre and post cholecystectomy screening of hepatobiliary tumours. Computerized tomography is associated with radiation and contrast exposure so is now less favourable. Magnetic resonace imaging is a relatively expensive method. The performance of ultrasound is less expensive and more readily available technique and has a sensitivity and 


\section{Cancer Therapy \& Oncology International Journal}

specificity of $57 \%$ and $94 \%$ respectively and accuracy $(90 \%)$ exceeding that of magnetic resource imaging/magnetic resonance cholangiopancreaticography for cholangiocarcionoma.
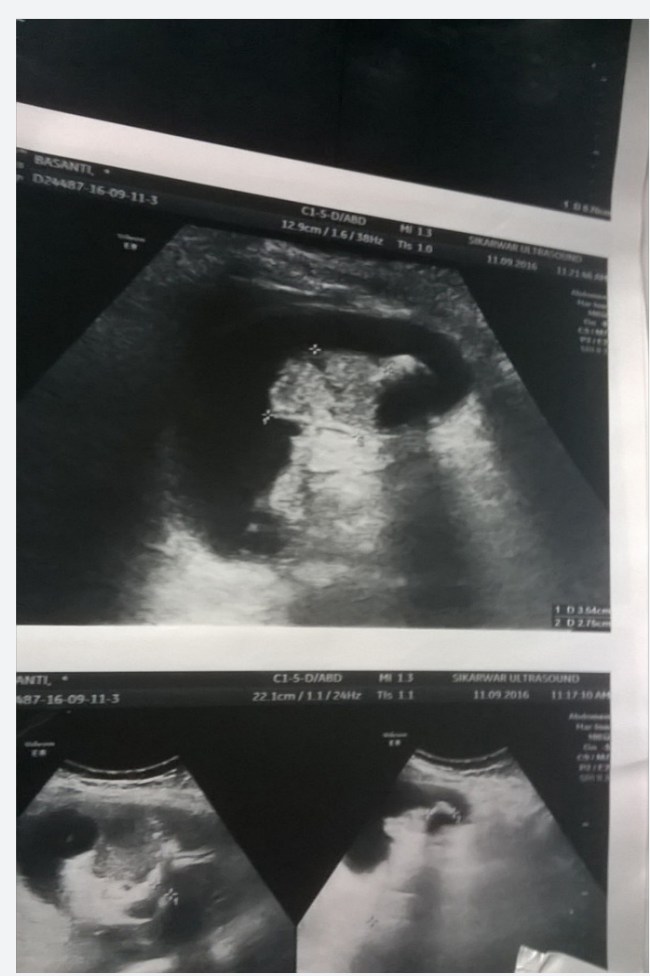

Figure 2: Carcinoma Gall Bladder with secondaries Liver.

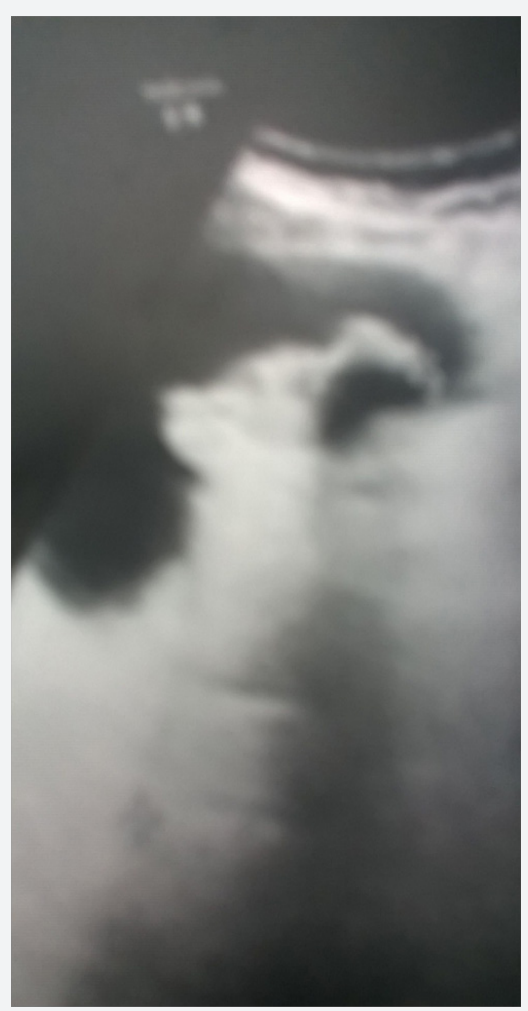

Figure 3: Carcinoma Gall Bladder.

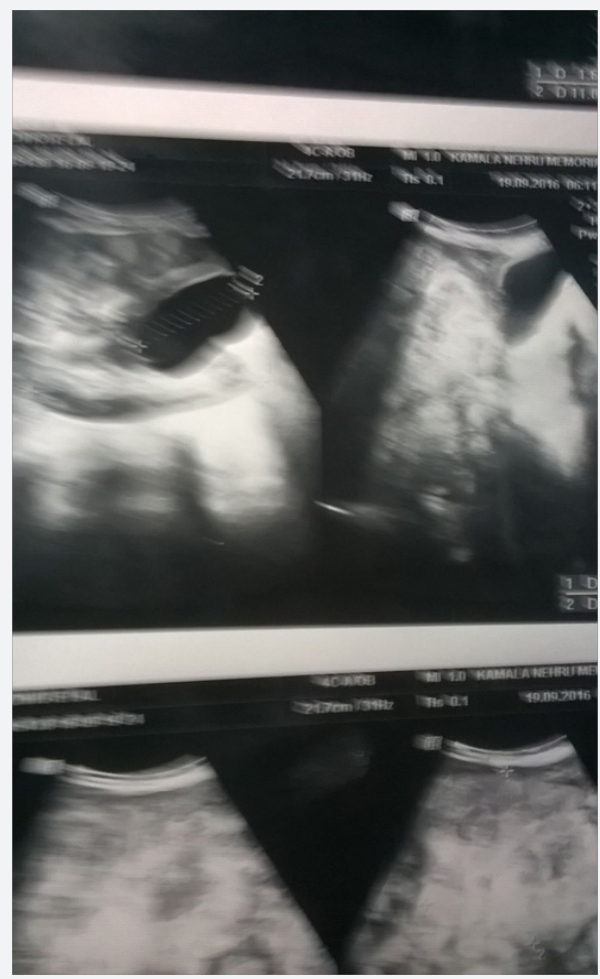

Figure 4: Carcinoma Gall Bladder with Secondaries liver.

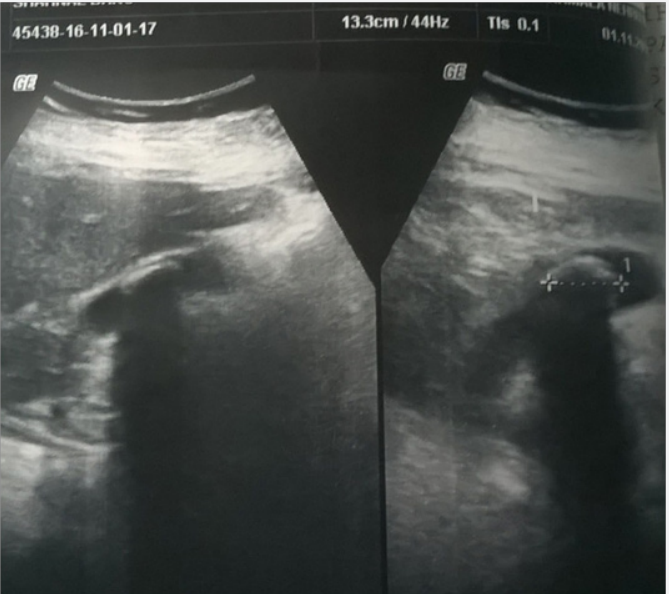

Figure 5: Carcinoma Gall Bladder with wall thickening.

Polyp of more than $8 \mathrm{~mm}$ size, especially if sessile and rapidly growing with presence of vascularity on Doppler ultrasound, simultaneous presence of gall stones, and older age at time of polyp diagnosis are risk factor for carcinoma of gall bladder [4-6] (Figures 2-6). There is some literature to suggest an inverse relationship between gall bladder polyp and stones. It is hypothesized that polyp either mechanically disrupt the formation of stones or that polyps are harder to diagnose radio graphically when stones are present. Three dimensional ultrasound diagnosis correlates well with two- dimensional ultrasound with regard to most gall bladder problems and could be sufficient as a standalone technique. In view of patient 


\section{Cancer Therapy \& Oncology International Journal}

comfort and no requirement for radiation it was considered that high resolution ultrasonograpohy is likely to become an important diagnostic modality for the differential diagnosis and staging of gall bladder polypoid lesions and early gall bladder cancer [7-11].

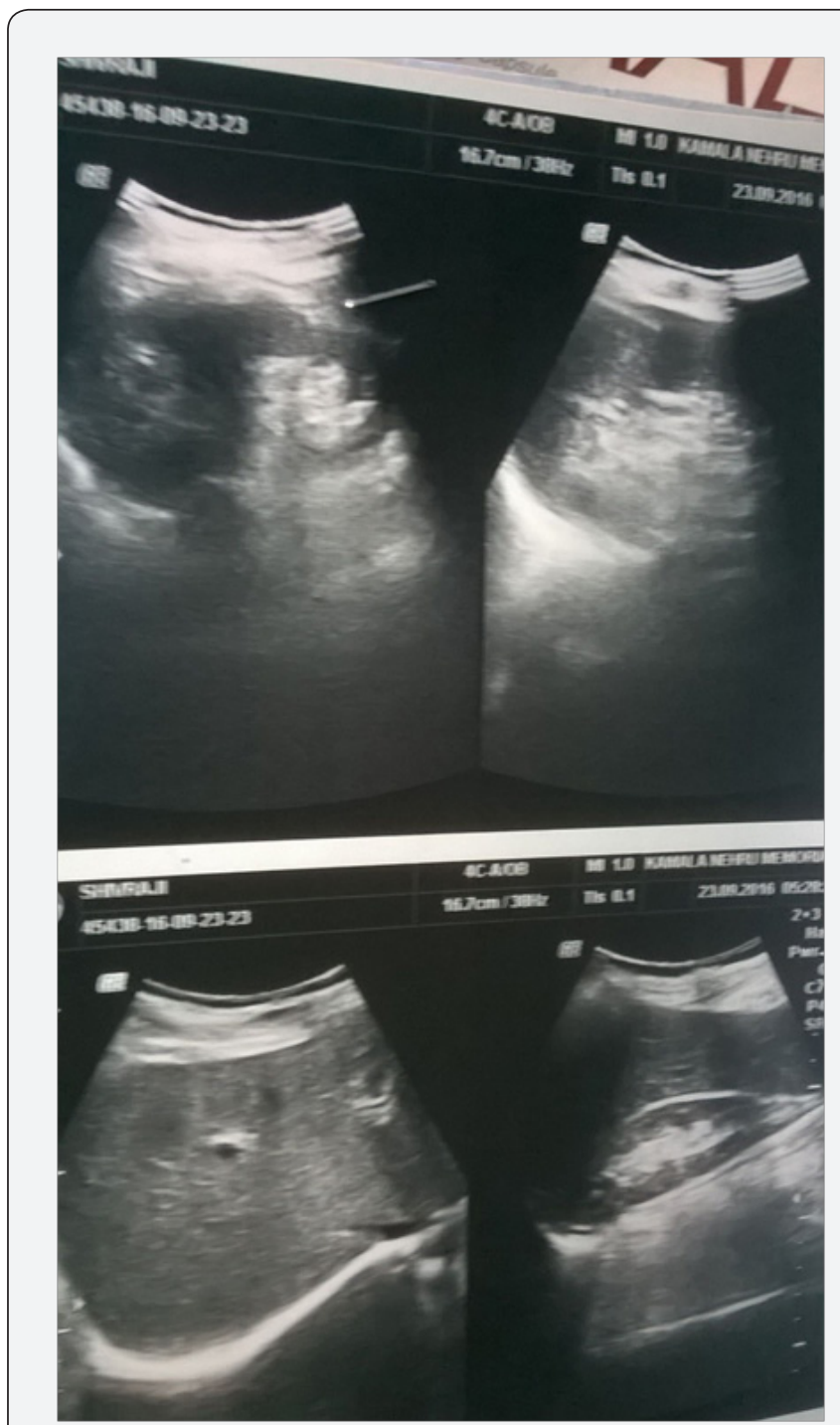

Figure 6: Carcinoma Gall Bladder with cholelithiasis.

In the harmonic mode, the level of artifacts generated by the body wall is reduced and contrast resolution is increased due to reduction in noise level. The visualization of gall bladder is improved in the harmonic mode. Ultrasonographic contrast enhancement patterns show characteristics associations with pathologic findings serve as valuable adjuncts in the diagnosis of gall bladder disease and differentiate gall bladder carcinoma from other polypoid gall bladder lesions. Distinguishing between non-neoplastic, neoplastic and potentially malignant lesion is a major dilemma and the therapeutic options for these lesions remains controversial. Endoscopic ultrasongography is considered to be superior to conventional ultrasound for imaging of gall bladder lesions, because endoscopic ultrasonography can provide high resolution image of small lesions with higher ultrasound frequencies (7.5-12 MHZ Vs. 3.5-5 MHZ).

Although Endoscopic ultrasonography was more accurate than untrasound, its accuracy for differentiating malignancy of less than $1.0 \mathrm{~cm}$, was low. Serial ultrasound scan for 6-12 months may be undertaken for Gall bladder polyp smaller than $1 \mathrm{~cm}$. Polyp size was also a predictor of the presence of adenoma. It was concluded in a report that there is a good correlation between the size of gall bladder polyp in ultrasound and the size in the histopathology report. In addition to serial untrasound scan, endoscopic retrograde cholengiopancreatiography may show a filling defect in the other hepatobiliary site tumours as well as obtain specimen for histopathology/liquid biopsy [12-15].

\section{Further implications}

The numbers of liver cancer and intrahepatic cholengiocarcinoma in available studies were low; hence the further studies should include more liver cancer and intrapepatic cholangiocarcinoma.

\section{Strengths and Limitations}

Two authors, Key word .dependently search data bases and selected studies, limitation included low number of cases in the studies, short follow-up time, and differences in study design. Changed bile flow pattern in patients with cholecystectomy/ cholelithiasis need to be studied so as to know there role in causation of hepatobiliary tumours. High rates of gall stones in Ganges belt of Uttar Pradesh may be associated with high rate of cholecystectomy as well as cholelithiasis. Post cholecystectomy ultrasound may show returned calculi in the cystic duct remnant or in common bile duct or operative complications.

\section{Reference}

1. Razumilava N, Gore GJ, Lindor KD (2011) Cancer Surveillance in patients with primary sclerosing cholangitis. Hepatology 54(5): 18421852.

2. Guo L, Mao, J, Li Y, Jiasoz, Guo J (2014) Cholelithiasis, cholecystectomy and risk of hepatocullular carcinoma: a meta analysis. J Cancer Res Ther 10(4): 834-838.

3. Charatcharoenwitthaya P, Enders FB, Halling KC, Lindor KD (2008) Utility of serum tumour markers, imaging and biliary cytology for detecting cholangiocarcinoma in primary sclerosing cholengitis. Hepatology 48(4): 1106-1117.

4. Zielinski MD, Atwell TD, Davis PW, Kendrick ML, Que FG (2008) Comparison of surgically resected polypoid lesions of the gall bladder to their pre-operative ultrasound characteristics. J Gastrointest Surg 13(1): 19-25.

5. Mainprize KS, Gould SW, Gilbert JM (2000) Surgical management of polypoid lesions of the gall bladder. Br J Surg 87: 414-417.

6. Lee JS, Lee KT, Jung JH, OK SW, Choi SC, et al. (2008) Factors associated with malignancy in Gall bladder polyps without gall bladder stone. Korean J Gastroenterol 52(2): 97-105.

7. Gallahan WC, Conway JD (2010) Diagnosis and management of gall bladder polyps. Gastroentrol Clin North Am 39(2): 359-367.

8. Stenberg B, Elliatt S (2010) Diagnosis of gall bladder problems using three dimensional ultrasound. Eur Radiol 20(4): 908-914. 


\section{Cancer Therapy \& Oncology International Journal}

9. Jang JY, Kim SW, Lee SE, Hwang DW, Kim EJ, et al. (2009) Differential diagnostic and staging accuracies of high resolutions ultrasonography endoscopic ultrasonography and multi detector computed tomography for gall bladder polypoid lesions and gall bladder cancer. Ann Surg 250(6): 943-949.

10. Paslawski M, krupski W, Zlomaniec J (2004) The value of ultrasound harmonic imaging in the diagnostics of gall bladder cholesterol polyps. Ann Univ Mariae Curie sklodowska Med 59(2): 292-297.

11. Hattori M, Inui K, Yoshino J, Miyoshi H, okushima K, et al. (2007) Usefulness of contrast enhanced ultrasonography in the differentia diagnosis of polypoid gall bladder lesions. Nihon shokakibyo Gakkai Zasshi 104: 790-798.

12. Numata K, Oka H, Morimoto M, Sugimari K, Krrisaki R, et al. (2007) Differential diagnosis of gall bladder disease with contrast enhanced

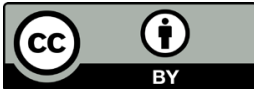

This work is licensed under Creative Commons Attribution 4.0 License

DOI: $10.19080 /$ CTOIJ.2017.04.555644 harmonic gray scale ultrasonography. J ultrasound Med 26(6): 763774 .

13. Cheon YK, Cho WY, Lee TH, Cho YD, Moon JH, et al. (2009) Endoscopic ultrasnongraphy does not differentiate neoplastic from non-neoplastic small gall bladder polyp. Word J Gastroenterol 15(19): 2361-2366.

14. Sugiyama M, Atomi Y, Yamoto T (2000) Endoscopic ultrasonography for differential diagnosis of polypoid gall bladder lesions, Analysis in surgical and follow up series. Gut 46(2): 250-254.

15. Escalona A, Leon F, Bellolio F, Pimental F, Guajardo M, et al. (2006) Gall bladder polyps; correlation between ultrasonography and histopathological findings. Rev Med Chill 134(10): 1237-1242.

\section{Your next submission with Juniper Publishers will reach you the below assets}

- Quality Editorial service

- Swift Peer Review

- Reprints availability

- E-prints Service

- Manuscript Podcast for convenient understanding

- Global attainment for your research

- Manuscript accessibility in different formats

( Pdf, E-pub, Full Text, Audio)

- Unceasing customer service

Track the below URL for one-step submission https://juniperpublishers.com/online-submission.php 